\title{
Use of Force and Human Rights under International Law ${ }^{1}$
}

\author{
By Kamal Ahmad Khan*
}

It is irony of time that oppression, pain and suffering exist even when man is trying to reach at the peak of civilisation. Millions of people have gazed the brutal horrors of history, with its countless examples of man's inhumanity to man. The vast majority of suffering and injustice in the world, today and spanning back thousands of years, can be directly attributed the idea of greed, hatred, evils of society and most important the belief of absolute authority of state. The belief in absolute authority which includes all belief in government is contrary to civilisation, morality rather than being force for order and justice. There is a harsh contrast between purpose of respecting authority in action the compliance of which makes us civilised and disrespect for authority which leads chaos and violence. The most of the injustice and destruction that has occurred throughout the world was not the result of people breaking the law, but rather the result of people obeying and enforcing the laws of various governments. A bad command is also bad to disobey. The right to life is the supreme human right and without effective guarantee for it, all other human rights would be meaningless. When a state violates human rights of its citizens, however, another state may violate the state's territorial sovereignty and protect the abused citizens under the doctrine of humanitarian intervention. Law of armed conflict and humanitarian right law are complimentary to each other. Both are intended to protect the lives, integrity and dignity of individuals, and both address issues related to the use of force. The very purpose of establishing United Nations was to maintain international peace and security in the world but there is controversy as to whether findings of the Security Council are conclusive as to legality, illegality and as to content of the applicable norms. The questions may also be raised as to the role of states interpreting the UN Charter while acting under the Charter and outside the Charter, judicial review of actions taken by the Security Council under Article 2(4) and by the individual state under Article 51 of the Charter. Humanitarian intervention, war as a means to show solidarity with the oppressed and the political will of the United Nations as to the last best hope of mankind also needs to be scrutinised. However the purpose of this paper is to analyse and evaluate the questions mentioned above and find out the answer and solution of the problem in the light of United Nations Charter, International Declarations, Convention, treaties and judgments of the International Court of Justice.

Keywords: UN Charter; Human Rights; Use of Force; International Declaration; International Court of Justice.

\footnotetext{
${ }^{*}$ LL.D. Associate Professor, Faculty of Law, University of Lucknow, Lucknow, U P, India.

${ }^{1}$ My thanks to the Omnipresent Almighty "Allah" for arousing the feeling of writing on the topic. I am equally thankful to writers who laid down the key stone for the present work. I am grateful to my colleague Dr. Ashish Srivastav for proof reading and formatting. My sincere gratitude to my wife, Razia Sultana for her constant patience and encouragement. My sincere thanks to ATINER for agreeing to publish the study and providing an opportunity to present my paper at Atiner conference in Athens, Greece.
} 


\section{Introduction}

Force has been a consistent feature of the global system since the beginning of the time. Early human beings often resorted to violent means to persuade their fellows to take a certain course of action or in order to obtain something another possessed. As the world began to be organised into political communities, force became a frequent means of interaction among these communities. With the emergence of the modern state system in the seventeenth century, armed conflict of all varieties proliferated. As the technology rapidly advanced, the destructive potential of warfare increased exponentially over the centuries. The different tool of war like machine gun, airplane, the submarine, the nuclear bomb and chemical weapons raised the horrors of war to an apocalyptic proportion. The devastating two world wars of the century resulted in death of over sixty million people breaking the spirit of entire culture but could not check the use of force at the global level. The US invasion of Panama, Soviet - Afghanwar, the 1991 Gulf War, Iran- Iraq War and recently use of force against Yugoslavia, Iraq, Afghanistan, Libya and Syria have proved that in modern times if international law is in some ways at the vanishing point of law, the law of war is perhaps even more conspicuously, at the vanishing point of international law.

\section{UN Charter and use of Force}

Article 2(4) prohibits member states to use force against territorial integrity or political independence of any state, or in any other manner inconsistent with the Purposes of the United Nations. Clause 7 of Article 2 further directs the state not to intervene in domestic matters of any state and encourages the member states to submit such matters to the settlement under the present Charter.

Chapter vii authorises the Security Council first to determine the existence of any threat to the peace, breach of the peace, or act of aggression and then make recommendations or decide what measures shall be taken in accordance with Article 41 and 42 to maintain or restore international peace and security. Article 41 talks about peaceful measure.

Article 42 provides that if the measures taken under Article 41 are inadequate or proved to be inadequate, coercive measures like action by air, sea or land force may be taken if necessary to restore international peace and security.

Article 51 of the Charter provides : 'Nothing in the present Charter shall impair the inherent right of individual or collective self-defence if an armed attack occurs against a Member of the United Nations, until the Security Council has taken measures necessary by Members in the exercise of this right of self-defence shall be immediately reported to the Security Council and shall not in any way affect the authority and responsibility of the Security Council 
under the present Charter to take at any time such action as it deems necessary in order to maintain or restore international peace and security.'

The debate as to whether judicial review of the Security Council's resolutions on the use of force is possible and desirable has revived with the end of the Cold War. In the Lockerbie case ${ }^{2}$ the International Court of Justice did not pronounce clear answer to the question of judicial review of Security Council's decision. Commentators are divided as to whether in principle judicial review should be available or whether it would be incompatible with the primary responsibility of the Security Council for the maintenance of international peace and security

\section{Legal or Non Illegal Use of Force}

The international legal system which relatively is under developed, is bound to recognise the legality or the not illegality of the individual use of force or its threat on the part of the states in certain situation. The determination of the legal or not illegal character of use of force or its threat in a particular situation does not solely depend on the answer of the issue whether or not such use or its threat been made in the exercise of self-defence. It may be legal or may not be illegal on grounds other than of self defence. How far has the threat or use of force been collectivised and how far has it been left in the discretion of the states? How far is the individual threat or use of force by states legally permitted or legally not prohibited, expressly as well as impliedly? These questions about the legal permissions or legal non prohibitions for the individual threat or use of force on the part of the states need to be examined under the Charter of the United Nations and other rules of international law. It would have legal character if it is not prohibited by an existing permissive rule of international law.

\section{Self Defence}

The law relating to self-defence has two questions to be answered:

1. How far does the Charter replace the traditional international law so far as the norm relating to self-defence is concerned?

2. Whetherthere is complete replacement or particular replacement or no replacement at all?

The commission of armed attack or its eminent threat is one of the problems of maintenance of international peace and security. The solution given under the Charter is the exercise of self defence under Article 51 until the Security Council takes measures necessary to maintain international peace and security. The exercise of self-defence which is a right of the state is subject to

${ }^{2}$ ICJ Report, 1998 
legal limitations. The limitations relate to the states who can exercise it, the states against whom it can be exercised, the subject matter for the protection of which it can be exercised, the time and the area within which it can be exercised, the method and the instrumentality by which it can be exercised and the degree which it can be exercised. These limitations lay down the conditions in conformity with which the exercise of self-defence is permitted.

\section{Who can Exercise the Right?}

One view is that Article 51 is applicable only to members, ${ }^{3}$ others extends its application to non members also. ${ }^{4}$ The second view interprets Article 51 in relation to Article 2, paragraph 6 of the Charter and holds that the right of self defence under Article 51 cannot be denied to non- members. States have right of self-defence under international law, but the question arises whether in a particular situation justifying the exercise of self-defence any state can exercise it irrespective of its being subjected to an armed attack or its imminent threat. It is the individual "self", it is one's own "self" which is defended.

In the case of collective self defence, it is not always necessary that the defender should be the victim of an armed attack or its imminent threat with the latter's consent. It is their broader "self" which is considered by them to have been subjected to armed attack or its imminent threat. It is the common objective or purpose of maintenance of international peace and security which is at stake and which needs to be protected and achieved.

\section{Against Whom the Right can be exercised?}

It is against the state or states that commit an armed attack or pose its imminent threat that the right of self defence can be exercised. Such armed attack or its imminent threat may be direct or indirect. ${ }^{5}$ Article 51 of the Charter only says; "if an armed attack occurs". It does not say that such armed attack has to be made by a member only. Thus it is clear that the right of self defence may be exercised against any state committing armed attack or posing its imminent threat.

\footnotetext{
${ }^{3}$ Kunz (1968) at 571; Greenspan (1959) at 27.

${ }^{4}$ Kelsen (1950) at 793.

${ }^{5}$ Article 2 paragraph 4 prohibits the threat or use of force not only when it is directed against the territorial integrity or political independence of any state but also when it is inconsistent with the purposes of the United Nations. Unlike the phrases "territorial integrity and political independence", the phrase "in any other manner inconsistent with the purposes of the United Nations", does not mention the "state". It means that if the threat or use of force is inconsistent with the purposes of the United Nations, it is not necessary that any state should be the sufferer of violation. The sufferer may be an international organisation, an individual.
} 


\section{Subject Matter of Self Defence}

Article 51 of the Charter only says that "if an armed attack occurs against a member," it can exercise its right of self-defence regardless of the possible motive of the state committing armed attack or posing its imminent threat. It is difficult to know motive of state. It is "self" of the state which is to be defended. The combined effect of Article 51 and Article 2(4) of the Charter is that an armed attack or its imminent threat may be directed against the territorial integrity or political independence of a state, or it may be directed against the purposes of the United Nations as far as they concern the defence of a state. Further question may arise: Can state exercise self-defence for the protection of its nationals and their property abroad? Can a state exercise it on the high sea for the protection of its economic interest? Can a state exercise it for the protection of its other rights? Can it be exercised for the protection of sovereignty of a state? The Charter under Article 51 has nothing to say about the questions raised above.

Bowett mentions certain substantive rights - the right of protection over national and economic rights to which self-defence pertains and for which it serves as a means of protection. ${ }^{6}$ However, the attacker may have any aim or objective in its mind which may be difficult to ascertain for the defender to know such aim or objective before it can exercise its right of self-defence.

\section{Action against which Self Defence can be Exercised}

It is only armed attack or also the imminent threat of armed attack or any other kind of action short of use of force or its threat entitles the state to use its right of self-defence. There is difference of opinion regarding situations which technically constitute an armed attack and the situations which constitute imminent danger or threat of armed attack. ${ }^{7}$ There are others who further extend the right to situations which constitute neither armed attack nor its imminent threat which emerge due to the violation of certain economic rights of state. ${ }^{8}$ The Charter does not answer the questions: what constitutes armed attack and its imminent threat? Nor does the traditional international law provide any help. It can be summarised as armed attack involves force or arms and has offensive destructive and illegal nature. Further the question whether an 'armed attack' is identical to aggression, has never been answered.

An armed attack may be direct or indirect. It is direct when a state directly employs its armed forces against another state. It is indirect when a state indirectly commits armed attack against another state by sending armed groups, irregulars or mercenaries which carryout acts of armed attack with sufficient gravity against another state. The imminent danger or threat of armed attack must be according to Caroline Doctrine, "instant, overwhelming, leaving

\footnotetext{
${ }^{6}$ Bowett (1958) at 29, 114.

${ }^{7}$ Starke (1972) at 29; Brownlie (1963) at 257; Singh (1956) at 24.

${ }^{8}$ Bowett (1958) at 109.
} 
no choice of means, and no moment for deliberation." ${ }^{9}$ However whether there exists an imminent danger of armed attack, it would depend on the individual circumstances of each case.

\section{Extent of Area to be defended}

The point about the area and space within which self-defence can be exercised raises following questions:

1. Does the exercise of right have to be confirmed to that particular area where the armed attack has actually been committed or its imminent threat has been posed?

2. Can it be exercised by a state outside its territory?

3. Can it be exercised in the territory of a third state which in no way is responsible for such attack or threat?

The answer of the above questions may be that if an armed attack has been posed by a state against a particular area in the territory of another state the latter state can exercise its right of self -defence in any area within the territory of another state would be considered to have been directed against the whole territory of such state. If a state allows its territory to be used by another state for launching armed attack against a third state, such third state can use force in self -defence against both the former states

\section{Means to be Adopted of Exercise of Right}

The question arises what is the instrumentality which can be used, the degree with which it can be used and the consequences which can be produced through such use; what are other legal requirements which have to be complied with?

The international law does not provide anything as regards the particular type of action which has to be taken by as state exercising its right of selfdefence. The commencement, duration and cession have always to be in full conformity with rules of international law.

\section{Principle of Proportionality and Necessity}

The purpose of right of self-defence is to repel or prevent an armed attack or imminent threat, not to punish the wrongdoer. A state exercising its right has to observe the principle of proportionality and necessity. Kelsen is of the opinion that the principle of proportionality requires that "acts taken in selfdefence must be proportionate to the danger threatened and they must not exceed in manner or in purpose the necessity provoking them." He further says

\footnotetext{
${ }^{9}$ Jennings \& McLeod (1938) at 89.
} 
that the preventive purpose of self-defence does not preclude interpreting the principle of proportionality to permit action directed to removing the danger. However the magnitude and intensity- the consequentiality of its effects must be proportional. No more force has to be used than is necessary for the purpose. There should be proportion between means and end.

What kind of action, with what degree, within what time and area would be justifiable on the ground of proportionality and necessity depend on the specific circumstances of a particular situation, compliance with the rules of warfare is necessary.

\section{Who will Report to the Security Council?}

The initial decision which would be an emergency decision has always to be made by the defending state itself. The condition precedent for the cession of the exercise of self defence is that not only the Security Council has to take measures but also that such measures must be necessary to maintain international peace and security in the situation. For this purpose, the unanimity of the permanent members of the Security Council is necessary in order to take an effective action. Such action cannot be taken if the permanent members themselves are divided. Their disagreement may cause more seriousness in the situation if such action is attempted to be taken by the general assembly which has neither the legal authority nor the capability for this purpose.

The right of self-defence under Article 51 is intended to be provisional right, it may become continuing right in the absence of an effective collective intervention by the Security Council. The right cannot be extended to cover the right of self-preservation or for its future security against a possible future armed attack or its imminent threat on the part of the same state or states. However, the right of self-defence is stopped, if and when the Security Council is able to take effective action, or its objective is achieved; armed attack is repelled by the defender or when the imminent danger of attack is removed by the defender or by the attacker.

\section{Collective Security and Use of Force}

Initially the intent behind the UN Charter was that control over the use of force would lie with the Security Council which would have a standing army at its disposal, but this plan has not been realised and the original Charter scheme has been modified through practice. The veto power possessed by the five permanent members of the Security Council under Article 27 generally blocks effective action by the Security Council. The Council in practice does not generally make express reference to specific Articles within Chapter 1l; it commonly makes a reference to Chapter 11 by using different words or 
phrase ${ }^{10}$.Similarly nowhere the word'collective security' has been used in the UN Charter. ${ }^{11}$ The notion of collective security raises the following questions:

1. What is nature and purpose of the collective security?

2. Is it an objective which needs to be achieved or a method by which an objective can be achieved or both?

3. Who has the authority and responsibility to ensure it and against whom?

4. When, where, how and how far to ensure it?

All the provisions are to ensure collective security for maintenance of peace. Security is the first necessity of every human being and even of every living creature. It is the first right - right to existence, which has to be ensured, whether it be the organisation of international community or a unit of a single human being. It was the only security consideration for establishing United Nations Organisation. The Preamble of the Charter emphasised "[...] to secure succeeding generations from the scourge of war, which twice in our life-time has brought unfold sorrow to mankind"

Now let us see how far the states are still mindful of that concern and are committed to their commitments, can well be judged on the basis of their behaviour in and out of the UN. In achieving a matter of common or collective interest, a collective mechanism should be given priority. The collective mechanism cannot be supposed to be the only and sole mechanism to achieve matters of common interest especially when there is no guarantee of its effective functioning. Regarding nature of obligation, Prof. Kelsen ${ }^{12}$ raises the question that some articles stipulate the word "shall" while some others providing that it "may" perform such function. He thinks that "the use of the word "shall" does not in any case constitute a legal obligation in the strict sense of the term, since the Charter does not provide sanctions to be inflicted upon the Security Council in case it does not perform the functions which it "shall" perform. ${ }^{13}$ In his view the word "shall," may be interpreted to constitute a "moral obligation". He emphasises that to impose a legal or moral obligation upon UN organ is problematical because fulfilmentof an obligation requires a decision of the organ through voting system which implies the possibility of a negative voting and hence a contradiction with the legal or moral obligation.

\footnotetext{
${ }^{10}$ Sarooshi (1999).

${ }^{11}$ Collective measures, Preventive or enforcement action(Article 2.5); Enforcement measures (Article 2.7); Maintenance of International Peace and Security (Article 24); Action with reference to threat to the peace, breaches of the peace, and act to aggression (Chapter vii); Provisional measures (Article 40); Measures not involving the use of armed force (Article 41); Action by air, sea or land forces (Article 42); Preventive and enforcement measures (Article 50); Enforcement action (Article 53).

${ }^{12}$ Kelsen (1950) at 264

${ }^{13}$ Ibid
} 


\section{Pre-Emptive Self Defence}

Pre-emptive self-defence is prohibited under U.N. Charter. Self defence is activated only in case of committed armed attack. The United States is one of the countries that accept this doctrine of pre-emptive self-defence. On the other hand except in its own case, the U.S is not willing to accept the same practice in relation to other states, such as in the case of Russia's intervention in Georgia in $2002^{14}$. Article 42, of the Treaty of Lisbon dealing with European Union's role in the common foreign and security policy, provides that if a member state is victim of an armed attack on its territory, the other member states are obliged to provide its assistance and support with all resources at their disposal, in accordance with Article 51 of the UN Charter. Thus it is clear that there is no legal norm which would allow collective self-defence in the name of European Union. By reading Article 51 it is clear that several requirements must be cumulatively fulfilled in order to use force in self defence legally:

1. Force may be used in self-defence only in relation to an armed attack

2. The armed attack has to be serious in nature (seriousness is to be decided by the Security Council)

3. The right of self-defence activates only in case of committed unlawful act.

4. The exercise of the right of self-defence must comply with the criterion of proportionality and necessity.

5. The force is to be used to shot back the attacker not to punish the state.

6. The force is legitimate only if there is actual attack or the attack has already been committed.

7. Measures taken in the exercise of the right of self-defence must be reported immediately to the Security Council.

\section{Nicargua Case and Pre-Emptive Self-Defence}

The International Court of Justice dealing with legality of the force used in Nicaragua by USA, laid down:

i. A state which is victim of an armed attack must declare that it was really attacked.

ii. There is no existence of a rule in the international law to authorise a state to use of right of collective self-defence on the basis of its own evaluation of the situation.

iii. There is no rule to allow exercise of collective self-defence in absence of request made by a victim state.

\footnotetext{
14 The United States protested when Russia used force, after hostage crisis, in Georgia on behalf of pre-emptive self-defence. Israel and Australia also support the policy while attacking on Palestine and participating in the mission 'Freedom for Iraq' respectively.
} 
iv. The state exercising the right must inform the Security Council.

\section{Bush- Pre-Emptive Doctrine}

The US attack on terrorists and states that harbour or support them, as well as on states that might someday use weapons of mass destruction against the United States and its nationals or against US allies raises questions concerning the permissibility of the use of armed force against terrorists and others in Afghanistan, Iraq and beyond.

There is widespread argument that an "armed attack must occur to attract Article 51 of the Charter. The use of the word "armed" in Article 51 is different from use of the broader phrase "force" in Article 2(4) of the Charter. The use of the word "armed" in Article 51 was intentional at the time of formation of the Charter and would not cover all sorts of force or weapon. ${ }^{15}$ The famous Carolinecase isoften mentioned concerning interpretation of Article 51. The United States in response to Canada's use of force on the necessity of selfdefence admitted that self-defence might justify the use of force, but only in case of which the necessity of the self-defence is instant, overwhelming, and leaving no choice of means, and moment for deliberation ${ }^{16}$. The same America in 1998 and 2001 claimed the right to use selective military force in Sudan and the Afghanistan in self-defence. However, use force for merely pre-emptive or retaliatory purposes is inconsistent with the purposes of Charter and is not authorised under Article 51 of the Charter ${ }^{17}$ The State attacked by non state terrorists has a legitimate claim against ${ }^{18}$ the harbouring state under international law and an international dispute can arise. Article 2(2) and 33 of the Charter recognise the need to settle international disputes by peaceful means. The court observed that mere knowing assistance to rebels in the form of the provision of weapons or logistical or other support might involve an impermissible use of force or intervention that can create state responsibility under international law and is thus subject to certain forms of sanctions but would not constitute an armed attack for purposes of self-defence. ${ }^{19}$

However, even knowledge of past and continuing al-Qaida terroristic attacks would not constitute Taliban control of or direct participation in future of al-Qaida attacks like the Sept.11, 2001 on the United States so as to justify the use of military force against Taliban in view of International Court of Justice's Nicaragua decision. Similarly alleged Pakistani military and other support of the Taliban and al-Qaida in the conflict of Northern Alliance and Iraq's alleged intelligence contacts with or training of, some members of alQaida attacks, cannot be said their participation in the Sept. $11^{\text {th }}$ attack. Iraq was the first test of the Bush administration's doctrine of preventive war. It was

\footnotetext{
${ }^{15}$ Murphy (2002) at 41.

${ }^{16}$ Moore (1906) at 412.

${ }^{17}$ Kunz (1968) at 571; Singh (1984) at 237; The Myth of Pre-emptive Self-Defence.

${ }^{18}$ Damrosch (1999) at 14.

${ }^{19}$ Nicaragua v. U.S., 1986, ICJ, p. 14.
} 
departure from previous conceptions of anticipatory self-defence as understood either in Caroline formulation or in the UN Charter framework. ${ }^{20}$

\section{Authorisation of Security Council}

The U.N.Security Council resolution 1373 condemned terrorist attacks on New York Washington and Pennsylvania on 11 Sept. 2001. The resolution did not declare that all states should combat by all means and take action against states that harbour, support, tolerate, or fail to prevent misuse of their territory by terrorists engaged in such terrorists attack but the resolution is expressly limited to action against perpetrators ${ }^{21}$

The Security Council's call upon states is relevant, but not necessary to the permissibility of self-defence action against Osama bin Laden and al-Qaeda as perpetrators of September 11 attack $^{22}$. It was not a call against a regime like the Taliban which is not a direct participant in al-Qaeda's attack. It is also not a call upon states like Iraq as Bush administration claims that Iraq harboured some member of al-Qaeda after Sept.11 attack.

However, in the absence of Security Council or appropriate regional authorisation to use armed force, ${ }^{23}$ the Bush doctrine of pre-emptive strike against states or groups whose weapons or weapons programs could pose a threat to United States or its allies is not permissible under the UN Charter. New strategic doctrine of pre-emption of President Bush is neo-Melian doctrine with a principle derived from the Athenians at Melos: "The strong do what they can and the weak suffer what they must" 24

The rules of international law on use of force are relatively easy to state, though they may be difficult to apply in practice. ${ }^{25}$ The rules are found in Charter and in customary international law. ${ }^{26}$ The Charter containsa measurethat may be taken or authorised by the Security Council, acting under Chapter vii of the Charter. Second, force may be used in the exercise of the right of individual or collective self-defence under Article 51 of the Charter. Another exception is taken to use force to avert an overwhelming humanitarian

\footnotetext{
${ }^{20}$ Sapiro (2003) at 599.

${ }^{21}$ U.N. Security Council Resolution 1773, U.N.Doc. S/RES/ 1773, 2001

${ }^{22}$ Paust (2002).

${ }^{23}$ Kuppuswami (2002).

${ }^{24}$ Thucydides (Crawley trans.) (1934) at 331.

${ }^{25}$ Weldock (1952) at 455; Bowett (1958); Brownlie (1963); Dinstein (2011).

${ }^{26}$ The Generally Assembly and International Court of Justice have contributed to the development of law through resolutions, Declarations and its judgments. General Assembly Resolution 2625(xxv).G.A. res. 3314(xxix); Declaration on the Non-Use of Force, G.A. res.44/22; Judgments of the I.C.J.: Corfu Channel (United Kingdom v. Albania); Military and Paramilitary Activities in and against Nicaragua (Nicaragua v. United States of America); Republic of Iran v. United States of America; Armed Activities on the Territory of the Congo.(Democratic Republic of Congo v. Uganda); The Uniting for Peace Resolution refer to as an alternative route if the Security Council is unable to act because of veto, the General Assembly may make recommendations but Jonson commenting on the provision writes- " Does it still serve any useful purpose"?, Jonson (2014).
} 
catastrophe or humanitarian intervention though it is not mentioned in the charter. The 2005 Summit of the Head of State and Government responded to the question whether there are significant shortcomings in the traditional body of rules on the use of force by state. Are existing rules adequate to meet current threats, especially from non- state actors and weapons of mass destruction?

"[...] that the relevant provisions of the Charter are sufficient to address the full range of threats to international peace and security. We stress the importance of acting in accordance with the purposes and principles of the Charter?"27

However, rules on the use of force in the Charter are adequate to meet new challenges if it is applied with the open mind and political will of the states including members of the Security Council and potential troop contributors.

\section{Self- Defence against Terrorist Attack}

Three questions arise in connection with self-defence against terrorist attack:

1. Does the right of self-defence apply at all in response to attack by nonstate actors, including transnational terrorist group?

2. Is there a right of anticipatory self-defence?

3. How does the requirement of imminence apply in relation to attacks by terrorists or with weapons of mass destruction?

The Security Council by its resolutions 1368 (2001) and 1373, (2001) reaffirmed the inherent right of individual and collective self-defence as recognised by the Charter of the United Nations and the state practice, including the practice of the members of the NATO, the members of the Organisation of American States and the silence of the International Court of Justice in armed conflict on the territory of Congo support such right. A subsequent Chatham House Study concluded that necessary and proportionate action could be taken where the territorial state is itself unable or unwilling to take the necessary action. ${ }^{28}$

\section{Anticipatory Self-Defence}

Answer to the question whether a right of anticipatory self-defence is available under the U.N.Charter remains controversial among states and authors. The United States and the United Kingdom maintained that force may be used inself-defence in the face of an imminent attack. The end of cold war

${ }^{27}$ General Assembly Resolution 60/1, para 79

${ }^{28}$ Wilmshierst (2006). 
and the new threats have not yet led to general agreement among states on the question of anticipatory self-defence.

The criterion of imminence raised a question in 1981 when nuclear plant of Iraq was attacked by Israel. The Security Council unanimously condemned the Israeli military attack a violation of Charter and the norms of international conduct. $^{29}$

\section{Humanitarian Intervention}

In the past humanitarian intervention was used in the context of the rescue by a state of its nationals abroad when the territorial state was unable or unwilling to do so. The recent trend is intervention by a third state or states to save people from their own government's action or inaction. ${ }^{30}$ There is no general doctrine of humanitarian intervention in international law. A limited use of force is justifiable in support of purposes laid down by the Security Council. Use of force without council's support is permissible when it is the only means to avert an immediate and overwhelming humanitarian catastrophe. ${ }^{31}$ Indiscriminate bombing for 35 days led to the loss of life and property of numerous innocent civilians, including those of Kosovo Albanians for whose protection this mindless violence is said to have been unleashed. NATO action was total violation of every relevant command of international law. Commenting on US policy James Petras writes:

"A new sense of imperial arrogance encourages Washington to intervene militarily in Europe; to redefine national boundaries; to extend and deepen its military alliances across Europe; to challenge European trading patterns and regulations; and to impose its own interpretation of free trade according to its own interest. In this light, Washington's NATO war in Yugoslavia can only be understood as part of a general expansion of US power."32

However, Washington NATO war in Yugoslavia can only be understood as part of a general expansion of the US power. Strategically Melosevic was in the way, the Albanians were useful stick to undermine his power.

In general based on literature on the subject, there are five factors that must be present in order to consider an act of aggression as a humanitarian intervention.

1. There must be some imminent threat by an organised group of perpetrators to some group of people who are imagined as victims and

\footnotetext{
${ }^{29}$ Security Council resolution 487, June 1981.

${ }^{30}$ No-Fly Zones in Iraq 1991 and Kosovo in 1999

${ }^{31}$ Wood (2013).

${ }^{32}$ Petras (1999).
} 
they are in need of recue and all other pacific efforts to rescue them must have been failed.

2. The consent of rulers who are source of their people's suffering is not necessary.

3. The intent of rescuers must be moral and ethical in nature and should not be based on self-interest (the acquisition of territory or resources) or national interest exclusively. The war must be publicly acknowledged as a humanitarian intervention. ${ }^{33}$

4. Such humanitarian intervention must be approved by the U.N. Security Council $^{34}$

5. The basic humanitarian goal must have a reasonable chance of success and once accomplished, the intervention must not mutate in to something else such as the destruction of the sovereignty of the state and its leaders, the acquisition of material resources or the implementation of a program of nation building. ${ }^{35}$

The operation in Kosovo (1999) is considered against the UN. Charter on the following grounds:

i. The force used by NATO was violation of Articles 2(4) and 24 of the Charter which give the Security Council, not the organisation like NATO and OSCE etc. primary responsibility for the maintenance of international peace and security.

ii. The Security Council under chapter vii must give explicit authorisation of use of force as a measure that shall be taken to maintain international peace and security.

iii. There was violation of Article 1 and Article 7 of the North Atlantic Treaty which provides:

"The parties undertake as set forth in the Charter of UN, to refrain in their international relations from the threat or use of force in any manner inconsistent with the purposes of the United Nations."

Thus the treaty does not affect the primary responsibility of the Security Council for the maintenance of international peace and security. However, the NATO operation in Kosovo affected the primary responsibility of Security Council because the force was used without authorisation of the Security Council. ${ }^{36}$

Now the question how far divergences from the prohibition on the use of force should be seen not as breaches but rather as exceptions to or modifications of the prohibition, is crucial also to any assessment of the role of international law in this area? This gives rise further to know whether the use

\footnotetext{
${ }^{33}$ Lang (2003).

${ }^{34}$ Chesterman (2001).

${ }^{35}$ Cook (2000).

${ }^{36}$ Petreski (2015).
} 
of force justified. The gap between the prohibition of the use of force and the practice seems striking to some commentators. Article 9.1 of the International Covenant on Civil and Political Rights reads:

'No one should be deprived of his liberty except such grounds and in accordance with such procedure as are established by law.'

The right to life is the supreme human right, since without effective guarantee for it, all other human rights would be devoid of meaning. The right of everyone to life, liberty and security of person is proclaimed in Article 3 of the Universal Declaration of Human Rights, International Covenant on Civil and Political Rights as well as African Charter on Human Rights and People's Rights and the Geneva Conventions (Laws of Armed Conflict \& Human Rights.)

Public International law governs the relations between states themselves, or with and between international organisations. As far as armed conflict is concerned, a distinction is made between the law that outlaws war and the law applicable in time of armed conflict.

Law of armed conflict and human right law are complimentary. Both are intended to protect the lives, integrity and dignity of individuals, and both address issues related to the use of force. The armed conflict regulate humanitarian issues in time of armed conflict, human rights law protects the individual at all times, in peace and war alike.

Most of human rights instruments allow governments to derogate, under strict conditions, from certain rights when confronted with serious public threat but no derogation are permitted under the law of armed conflict in case of right to life. It strikes a balance between military necessity and humanitarian objectives. In this background following questions may be raised:

Are war and violence the best means to promote solidarity with oppressed? Does the war raise the question for the future of global governance?

Does the political will exist at the United Nations as the last best hope of mankind?

Is there need to reform international law and international institutions?

Whether humanitarian intervention is legal under international law?

The rules of International Law on the use of force are relatively easy to state though they may be difficult to apply in practice. ${ }^{37}$ The use of force associated even with war is an instrument of politics and to explain this claim adequately is to account for an ethics of the use of force. The recent experience of the use of force include force used to intervene in civil wars, ethnic cleansing and genocide, war between states, force used in response to terrorism, force used to prevent the development of the instruments of war, force used to gather intelligence etc.

${ }^{37}$ Wood (2013) at 351. 
The legal regulation of the use of force and its threat on the part of the states in their international relations has been one of the most important problems of international law. The problem concerns the determination of the legal permissibility, the legal non-impermissibility of the use of force and its threat- how far is it legal, non-illegal and illegal?

The problem also concerns the determination of the dividing line of jurisdiction between collectivism and individualism in regard to the use of force and its threat- how far has it been left in the dual mechanism operate as a substitute for collective mechanism in upholding the rules of international law?

\section{Prisoners of War and their Treatment}

The extensive procedures used in Vietnam reflected a broader U.S. policy of liberally granting prisoner-of- war status to combatants, other than those engaged in terrorism, spying or sabotage, ${ }^{38}$ as noted by a senior military lawyer, who was the chief military legal advisor to the U.S. military forces in Vietnam from 1964 to 1966 :

The U.S. policy was to do all in its power to alienate the plight of American prisoners. It was expected that efforts by the United States to ensure humane treatment for Vietcong and North Vietnamese Army Captives would bring reciprocal benefits for American captives. ${ }^{39}$ However the procedure tailored to Vietnam, were not applicable to subsequent U.S.Military operations like Panama and war in Afghanistan and Iraq. In subsequent conflict, it was left to commanders at the theatre level or lowers to determine what procedures would be used to make status determinations. U.S. military officials used more informal procedures that were better suited to the circumstances of the conflict.

\section{Interrogation and Treatment Standard}

New techniques ${ }^{40}$ were prepared by behavioural scientists:

- Aggressive interrogation techniques- sleep deprivation, death threat and water boarding at Guantanamo.

- Category first included yelling at the detainee, techniques of deception, and false flag.

- Category two included stress position, use of false documents and up to 30 days of isolation, deprivation of auditory stimuli; prolonged interrogations, changing rations to MRES, removal of clothing, force grooming and exploitation of detainee phobias( i.e. Fear of dog)

\footnotetext{
${ }^{38}$ Prugh (1975) at 66. (All combatants captured during military operations were to be accorded prisoner-of-war status irrespective of the type of unit to which they belong.)

${ }^{39}$ Schoettler, Jr (2015) at 156.

${ }^{40}$ Available on www.gpo.gov/fdsys/pkg/CPRT-110SPRT48761/pdf/
} 
- Category third which included use of scenarios threatening death to the subject of interrogation or his family exposure of the subject to cold weather or water, use of dripping water to induce 'misperception of suffocation (water boarding) and use of mild non-injurious physical contact.

The international humanitarian law seeks to protect civilians from unnecessary harm during armed conflict. The Protocol 1(1977) to the Geneva convention require a military force to take all feasible precautions in the choice of means and methods of attack with a view to avoiding and in any event minimizing incidental loss of civilian life. Human Right Watch quoted interview of a resident, "A man (soldier) came and ran his hand through my hair, pulled out some hair from my beard [...] the most awful thing was how they were taking our picture and we were completely naked. It was completely humiliating. ${ }^{41}$ It also happened during first months after the United States set up the Bagram facility in Afghanistan in late 2001 that the detainees faced harsh treatment, striped to their undershirt and underwear ${ }^{42}$. US military personnel too shifts, keeping the detainees awake by banging on the metal wall of their cells. Detainees were terrified and disoriented by sleep deprivation for several weeks; they were made to stand upright for long time with a bright spotlight shining directly into their eyes. ${ }^{43}$ At Bagram US troops made the detainees lie on the ground at one point, naked and pinned them down with a chair shackled continuously even when sleeping and forbidden from talking with other detainees ${ }^{44}$.At Kandahar airbase the detainees were subjected to sleep and light deprivation and prolonged isolation and the room temperatures ranging from 100 degrees to 10 degrees Fahrenheit ${ }^{45}$ A Pakistani fighter released from Guantanamo in July 2003 told that prisoners were handcuffed forced to sit with their legs stretched and hand behind them, the whole body bent onto the legs all the way, they were beaten mercilessly with boots kicking in back and kidneys and were forced to lie on the frozen ground until they were numb with cold. ${ }^{46}$ The reply of US Intelligence Military Officer to a protesting prisoner at Guantanamo Jail "You are in a place where there is no law, we are the law" is enough to say what the law is in the eyes of powerful great nation.

Civilians who were not taking part in hostilities were targeted. Civilian died and injured during arrest operation, their property and homes were destroyed and looted. ${ }^{47}$

\footnotetext{
${ }^{41}$ Human Right Watch, March 10, 2003.

${ }^{42}$ Ibid

${ }^{43}$ A journalist with a British Broadcasting Corporation Panorama program interviewed the detainees , July 203 , available at http://News.bbc.co.uk/no1/spl/hi/programmes/panorma/insideguantanamo.txt

${ }^{44}$ Associated press, March 14, 2003. Human Rights Watch interview with Ahmad Khan, Zurmat, Paktia, March 10, 2003.

${ }^{45}$ The New York Times, March 4, 2003

${ }^{46}$ The Guardian, December, 3 , 2003

${ }^{47}$ Human Rights Watch, Afghanistan : "US Military Should Investigate Civilian Deaths," press release, Dec. 13, 2003-2004
} 
US forces were used by interpreters as proxies in local rivalries, and to extort money from local residents or to intimidate opponents. Karzai government also raised concern with US officials about use of excessive military force. ${ }^{48}$ They also blew doors open with grenade rather than knocking and roughly treated women and children. ${ }^{49}$

However, the arranged murder of Saddam Husain ${ }^{50}$ by shabby trial, choreographed by United States America marred by serious flaws and inhuman barbaric treatment by the civilised world with detainees at Bagram Air Base, Abugharib Jail, and the Guantanamo raises following questions:

Can we call us civilised?

Is there requirement of any particular place and specific persons for application of the concept of 'Rule of Law'?

Can we call the wandering nomads uncivilised as they were not aware of such brutal treatment with human beings?

Science is a good servant but a bad master no doubt but what we call the civilised nation that uses behavioural scientist to find out barbarous torture techniques to extract confession from persons under their custody to fulfil their intended ambitions.

\section{Legal Standards Applicable to Physical Treatment of Detainee}

Article 3 to Geneva Convention, Protocol 1 of 1997 to the Geneva Convention and Human Rights law prohibits torture and other cruel inhuman humiliating or degrading treatment or punishment. ${ }^{51}$ Prolong shackling of detainees violates international law prohibitions against mistreatment and amount torture. The U.N. Sectary General has also referred to shackling as an example of a prohibited method of torture. ${ }^{52}$. Persons detained during internal armed conflicts must be treated in accordance with Article 3 common to the 1949 Geneva Conventions, customary international humanitarian law and due process requirements of human rights law. During an internal conflict, persons apprehended for taking part in armed conflict may be prosecuted for taking up arms against the government. This means that the Afghan government may prosecute persons apprehended during the fighting for violations of Afghan law. Such prosecutions must be carried out by tribunals that meet international due process standard. ${ }^{53}$ During international armed conflict, civilians may be detained for imperative reasons of security, but they may not be held indefinitely without review. The Forth Geneva Convention permits detention

\footnotetext{
${ }^{48}$ Human Rights Watch, Dec. 5, 2003, Feb. 2004.

${ }^{49}$ Human Rights Watch email-exchange with UN official in Afghanistan, Feb. 2004.

${ }^{50}$ Quoted by Noorani (2004).

51 Protocol 1 1977, Additional to Geneva Conventions of 1949, Protocol 1, Article 75. , G.

A,.Res. 39/46, annex, 39, UN. Doc A/39/51, ICCPR, Arts. 7. , 4 (2)

52 Notes by the Secretary General, 1994, A/49/594, para 13.

${ }^{53}$ Zara Khan, Missing Businessman in US. Custody, Associated Press, Sept. 17, 2003.
} 
only if the security of the detaining power makes it absolutely necessary. ${ }^{54}$ Even then the detainee must be presented before an appropriate court or administrative board by that purpose. However by flouting this standard,the United States violated international law. ${ }^{55}$

\section{Libya}

The use of force in Libya raised the question whether the intervening states were allowed to actively pursue regime change or to protect civilian catastrophe. There was two approaches of NATO - one to protect the civilian from further attack by halting advance of Gaddafi troops towards Benghazi and secondly to remove Gaddafi from power or regime change. The NATO went for the second option. ${ }^{56}$ The Arab League Secretary -General Amre Moussa said that it is not to give the rebels support. It is not a question of supporting a regime, a government or a council. It is to save the situation from further, bloody deterioration. ${ }^{57}$ But NATO made it clear that they viewed regime change as a political objective, not a military one. ${ }^{58}$ On the other ${ }^{59}$ hand; politically the allies concluded that the only plausible solution to the crisis was for Colonel Gaddafi to relinquish. The BRICS countries and others stressed,"We are opposed to any attempt to wilfully interpret the resolutions or to take action that exceeds those mandated by the resolutions." ${ }^{\circ 0}$ South Africa also branded the operation as "beyond their letter and spirit" and warned against "advancing political agenda that go beyond the protection of civilian mandates, including regime change." Brazil, Russia and China maintained that international community should remain politically impartial regarding the outcome of the conflict and not to support openly either of the parties or to identify with their political objectives. ${ }^{61}$

\section{Iraq}

The role of the United Nations Monitoring Verification and Inspection Commission assigned by the UN Security Council under resolution 1284 of

\footnotetext{
${ }^{54}$ Forth Geneva Convention, art. 42.

${ }^{55}$ Forth Geneva Convention says that prisoners of the occupying power who do not qualify for the full protection of POW status are entitled to "humane treatment" and to the "judicial guarantees which are recognised as indispensable by civilized people." See also Hamadi v. Rumsfeild (547 US, 507) and Hamdan v. Ramsfeild (548 US, 05-184)

${ }^{56}$ Washington Post, March 20, 2011; The Telegraph, March 21, 2011; The Guardian, March 23, 2011.

${ }^{57}$ The Call in Libya Is Not Regime Change, New York Times, March 23, 2011.

${ }^{58}$ Libya: William Hague Rules Out Invasion, The Guardian, March 21, 2011. (President Obama on March 28.2011 outlined the political purposes of the operation: "Libya and the world would be better off with Gaddafi out of power").

${ }_{59}$ New York Times, Libya's Pathway to peace.

${ }^{60}$ UN Security Council Provisional Verbatim Record of 653 meeting, S/PV, 653, May 10, 2011.

${ }^{61}$ Genser \& Ugarte (2014) at 425.
} 
1999 and 1441 of 2002 provided an opportunity to Bush-Blair alliance to wage war against Iraq. Blix was juridically obliged to inspect weapons of mass destruction in Iraq but he went beyond the very promise of the UN by focusing on the "proof of the destruction of WMD and unfolding a new chapter of unresolved questions. The vindication of US provocative morality changed the issue "Weapon of Mass Destruction" in to issue of "regime change" in Iraq. This "choice" of United States raised a serious issue of sovereignty of the larger world and sanctity of the United Nations. The Blix report was like a cat and mouse game putting Iraq in a perpetual crisis. The US succeeded in hijacking the Iraqi issue as an agenda which prevailed over a decade and the timed world and UN has been a positive spectators. ${ }^{62}$

Toney Blair's moral case for war based on assumption that "there will be fewer deaths and less suffering of Iraqi people, if war occurs and Saddam Husain is deposed than he remains in power", is surprising. The operation desert storm lead cumulative effect ${ }^{63}$ on Iraqi civilian increasing child mortality rate more than three times higher than it was in 1986. Psychological cohesion of the people disturbed increasing juvenile delinquency, begging and prostitution disrupting family life. The political economic and social rights of the people crippled. ${ }^{64}$

\section{Scope of Application of Humanitarian Law}

The international law of armed conflict applies to all parties in all armed conflicts, irrespective of the legality of the resort to force. It would be incorrect to suggest that prisoners belonging to a party alleged to be acting wrongfully are not protected by International Humanitarian Law, or conversely that the victim of an act of aggression has the right to attack the civilian population of the aggressor. ${ }^{65}$ Article 51 (2) of Protocol 1 prohibits attacks designed to spread terror among the civilian population. Now the question arises what constitute the military objects? Article 52 (2) of the Protocol defines military objectives as 'those which by their nature, location, purpose or use make an effective contribution to military action and whose total or partial destruction , capture or neutralisation, in the circumstances ruling at the time, offers a definite military advantage. API, Article 56 prohibits attacks on dams, dykes and nuclear electrical generating stations if such attack is likely to release dangerous forces which would cause severe losses to the civilian.

\footnotetext{
${ }^{62}$ Khan (2003).

${ }^{63}$ Security Council resolution 1999.

${ }^{64}$ www.pubications. Parliament.UK/pa/cm 199900/cmselect/cmintdev/67/6707htm

It is important to mention here that both the Anglican and Roman catholic Archbishops of England contradicting the Tony Blair's moral case for war issued a joint statement on Feb.20,2003: "The events of recent days show that doubts still persists about the moral legitimacy as well as the unpredictable humanitarian consequences of a war with Iraq."

${ }^{65}$ Evans (2003).
} 


\section{Prisoners of War and Civilians}

The protection of prisoners of war is that they are not in the hands of the individual units or commanders who have captured them, but in those of the detaining state which is responsible in international law for their good treatment. ${ }^{66}$ Prisoners of war are neither criminal nor hostage. The detaining state is under an absolute duty to ensure that they are not murdered tortured, illtreated. The detaining authority may question them but it is illegal to coerce them to provide any other information except their name, rank date of birth and military number. ${ }^{67}$ Civilians are entitled to a standard of treatment effectively analogous to that accorded prisoners of war. Civilians must not be subjected to reprisals or collective punishments ${ }^{68}$, held hostage or otherwise ill-treated. ${ }^{69}$

Suggestions for Implementation of humanitarian law are

1. State's responsibility for violations committed by their armed forces

2. State's duty to disseminate IHL and provide for its instruction to their armed forces

3. Criminal investigation and, where appropriate, prosecution of individuals accused of violations

4. External scrutiny and pressure by third parties.

\section{Conclusion and Suggestions}

The purpose of the Charter is to prohibit war among nations. As a matter of fact, however, the word 'war' itself does not appear in its text, with the exception of the Preamble, which states,

"[...] to save succeeding generations from the scourge of war, which twice in our life-time had brought untold sorrow to mankind".

This wording indicates that the founding fathers of the Charter were building on past experiences and were trying to avoid new wars in future. Indeed, there have been no more world wars since the coming into force of the Charter but it is difficult to argue that only the provisions and mechanisms will bring fruitful result. Other considerations: the willingness of the powerful states to avoid major military confrontation among themselves, nuclear deterrence playing a major role in this respect.The credit of international law and the Charter is at stake as its rules and mechanism are not able to prevent or control the threat of use of armed force by states, or have to cope with new and

${ }^{66}$ Geneva Convention 1ll, Article 12-13

${ }^{67}$ Geneva Convention 111, Article 17

${ }^{68}$ Geneva Convention IV Article 33

${ }^{69}$ Ibid, Article 34 
unforeseen forms of conflicts ${ }^{70}$.The war must be waged by a legitimate power. Extension of empire, difference of religion desire for personal glory and prestige and to avenge wrongs cannot be just cause of war. War does not seek to validate a given international order but as with any act of politics, war clears the space for a greater ordering injustice than existed before. So long as the intention of war is peace, and war is fought by means appropriate to peace, it will enable but not guarantee post bellum political reconciliation.In times of war, the law falls silent but in the time of today's conflicts law shouts which raises another question, 'Is it shouting the right answer'. The popular modern democracies will not support military operations, no matter how worthy the political objective, if people believe that the war is being conducted in an unfair, inhuman or iniquitous way. War occurs always in a political context, not in a political vacuum where other states and their interest and populations can be ignored, where passion and might replace reason absolutely and where armed force is the only form of power. In general terms, the aim and result of war are to change or preserve a political order. War to be just, it must be good for both parties and strive towards reconciliation between the adversaries. ${ }^{71}$ The real evil in war is love of violence, revengeful cruelty, fierce and implacable enmity, wild resistance and the lust of power. The just warrior is not one who denies the evil of war, but who understands the presence of evil in the world and carries out her duty attempting to retain her humanity in its midst. Power is the capacity of a political unit to impose its will on others and an instrument essential to the exercise of political authority. Augustine finds good even in evil governments through the ways even unjust governance, is superior to no government at all. He rejects the notion of war as a glorious endeavour to be sought for its own sake or for the sake of testing valour and suffering the mettle of young men. War, therefore, cannot be waged in the name of freedom or democracy. ${ }^{72}$ No war can claim peace as the goal unless they are able to describe the nature of the peace in terms of society defended and the crime defended against. The right intention places the end of peace in front of all other considerations including right authority, just cause and reasonable hope of success. Justice does not recognise domestic boundaries and challenges. Wars are always damaging: they always involve bringing some disorder in to being.

However, we have guided missiles but unguided man. when the earth is changed, everywhere nature has disappeared and human arts has taken its place, independence and natural liberty has given way to laws and to slavery and philosopher searches for man and does not find him, there is need to change the philosophy of life from metaphysical to ethical one, though a herculean task but necessary to bring peace in the world. Success cannot be judged on the scale how much nuclear weapons we have developed, how far

\footnotetext{
${ }^{70}$ Sherwani (2013), 'Cry of UN Security Council Over American Arrogance', Lucknow, India, "I am fiction, I am a fraud, I am a captive, I am a slave; I am governed by the reign of force, I was born to deceive you all; Come to my rescue, if you are brave."

${ }^{71}$ De Vitoria (1991) at 21.

${ }^{72}$ von Heyking (2001) at 152.
} 
we have reached in the space and how much we achieved thorough scientific inventions but how much we have been able to establish peace and security in the world. History knows the fate of over ambitious rulers and nations, they are no more today. Same will happen tomorrow. So, back to ethics with fine tune, devoid of all kinds of dogmas open to question having an experimental base.

\section{References}

Bowett, D.W. (1958).Self-Defence in International Law.Manchester: Manchester University Press.

Bradford, W. (2004). 'Barbarians at the Gates: A Post- September $11^{\text {th }}$ Proposal to Rationalize the Laws of War', in 73 Miss. L.J. Vol. 73:639

Brownlie, I. (1963). International Law and Use of Force by States. Oxford: Clarendon Press.

Chesterman, S. (2001). Just War or Just Peace: Humanitarian Intervention and International Law. Oxford: Oxford University Press.

Cook, M.L. (2000).'Immaculate War: Constraints on Humanitarian Intervention', in Ethics \& International Affairs, Vol: 14(1): 55-65.

Damrosch, L.F. (1999). 'Sanctions against Perpetrators of Terrorism', in 22 Hous. J. Intl.L. Vol. 22(1):63-74.

de Vitoria, F.: Political Writings, ed. A. Pagden \& J. Lawrence (1991) Cambridge, Cambridge University

Dinstein, Y. (2011). War, Aggression and Self-Defence, $5^{\text {th }}$ ed. New York: Cambridge University Press.

Evans, M.D. (2003). International Law, $4^{\text {th }}$ ed. Oxford: Oxford University Press.

Genser, J. \& B.S. Ugarte (2014). The United Nations Security Council in the Age of Human Rights. New York: Cambridge University Press.

Greenspan, M. (1959) The Modern Law of Land Warfare. University of California press.

Jennings R.Y. \& A. McLeod (1938). 'The Caroline And McLeod Cases', in AJILVol. 32(1): 82-89.

Jonson, L.D. (2014). 'Uniting for Peace”, Does It Still Any Useful Purpose?' inAJIL 108: 106-115.

Kelsen, H. (1950). The Law of United Nations. A Critical Analysis of Its Fundamental Problems. London: Stevens \& Sons Ltd.

Khan, A. (2003). 'Politics of Making a Case for Attack on Iraq', in Mainstream, February 22.

Kunz, J.L.b (1968). The Changing Law of Nations: law, Columbus: Ohio State University Press. essays on international

Kuppuswami, M. (2002). 'A Return to Gunboat Diplomacy?', in Bus. Times Sing, Dec. $3,2002$.

Lang, Jr. A.F. (2003). Just Intervention. Washington D.C.: Georgetown University Press.

Matheson, M. J. (1987). 'The United States Position on the Relation of Customary Law to the 1977 Protocols,Additional to the 1949 Geneva Conventions" in A.M.U.J. Intll.\& Pol', 419.

Moore, J.B. (1906). A Digest of International Law. US Government Printing Office.

Murphy, S.D. (2002). 'Terrorism and the Concept of Armed Attack in Article 51 of the UN Charter' in Harv. International Law JournalVol.43:41-52.

Noorani, A.G. (2004) 'A murder has been arranged', inHindustan Times, New Delhi, January 2004, p.12. 
Paust, J.J. (2002). 'Use of Armed Force against Terrorists in Afghanistan, Iraq, and Beyond', inCornell International Law JournalVol.35(3): 533-557.

Petras, J. (1999). 'NATO Saving Kosovo by Destroying It', in Economic and Political Weekly, June 5, 1999

Petreski, M. (2015). 'The International Public Law and the use of Force by the States', in Journal of Liberty and affairs Vol. 1(2): 94-102.

Prugh, G.S. (1975). Law at War: Vietnam 1964-1973. US Department of the army.

Rodriguez, C. L. (1999). 'Slaying the Monster: Why the United States Should Not Support the Rome Treaty', in 14 A M. U. INT'L L. Rev. Vol. 14:805.

Sapiro, M. (1993).'“Iraq: The Shifting Sands of Preemptive self-defence', in A.J.I.L.Vol. 97: 599-607.

Sarooshi, D, (1999). The United Nations and the Development of Collective Security, Oxford: Clarendon Press,

Schindler, D. \& J. Toman (2004). The Laws of Armed Conflicts : A Collection Of Conventions, Resolutions \& Other Documents. Leiden: Nijhoff

Schoettler, Jr., J. A. (2015).Detention of Combatants and the War on Terror. Oxford: Oxford University Press.

Sherwani, M. K. (2013). 'Cry of UN Security Council Over American Arrogance', http://portugheis.livejournal.com/251779.html

Singh, J.N. (1984). Use of Force Under International Law. Harnam Publications.

Singh, N.M. (1956), 'The Right of Self Defence in Relation to Use of Nuclear Weapons' in India Yearbook of International Affairs 3, in McDougal, M.S. \& F.P. Feliciano (1994) The International Law of War. New Haven: New Haven Press, p. 9.

Starke J.G., (1972) An Introduction to International Law.Oxford: ButterworthHeinemann.

Thucydides, The Complete Writing of Thucydides: The Peloponnesian War (Richard Crawley (trans.), (1934). New York: Modern Library

von Heyking, J. (2001). Augustine and Politics as Longing in the World. Colombia and London: University of Missouri Press.

Weldock, C.H.M. (1952). 'The Regulation of the Use of Force by Individual States in International Law', in Collected Courses of the Hague Academy of International LawVol.81: 451-517.

Wilmshierst, E. (2006). 'The Chatham House Principles of International Law on the Use of Force in Self-Defence', in I.C.L.Q. Vol.55:698-972.

Wood, M. (2013). 'International Law and the Use of Force', in Indian Journal of International LawVol. 53:345-367. 